\title{
Influences of Carbon Sources and their Concentrations on Shoot Proliferation and Rooting of 'Hosui' Japanese Pear
}

\author{
Masanori Kadota ${ }^{1}$ and Yoshiji Niimi \\ Faculty of Agriculture, Niigata University, 2-8050 Ikarashi, Niigata 950-2181, \\ Japan
}

Additional index words. hyperhydricity, Pyrus pyrifolia N., sorbitol, sucrose

Abstract. We investigated the influence of sorbitol, sucrose, fructose, glucose, maltose, lactose, and mannitol carbon sources at various concentrations on shoot proliferation, hyperhydricity and rooting of pear. Shoot tips were cultured in woody plant medium (Lloyd and McCown, 1981) containing $11.0 \mu \mathrm{M}$ 6-benzyladenine, $0.5 \mu \mathrm{M}$ indole-3-butyric acid, $0.8 \%(w / v)$ agar and 30, 60, or $120 \mathrm{~mm}$ of each of seven carbon sources for eight weeks. Sorbitol at $60 \mathrm{~mm}$ was the most effective carbon source for shoot proliferation. Using $30 \mathrm{~mm}$ sorbital and 30 and $120 \mathrm{~mm}$ sucrose resulted in a high number of hyperhydric explants. Shoots rooted with $60 \mathrm{~mm}$ glucose, sucrose and sorbitol in media; media with sucrose resulting in the highest rooting frequency, root number and root length. Shoots failed to root when fructose, lactose, maltose, or mannitol were used.

Cultured plant tissues need a continuous supply of carbohydrates from the medium to encourage growth and to survive in vitro; photosynthetic activity of cultured tissues is reduced by the use of suboptimal light intensity, limited gas change and high relative humidity (Kozai, 1991). Therefore, sugars, such as sucrose, glucose, and sorbitol, are generally added as a carbon source.

The type of carbon source and its concentration affects the regeneration of adventitious shoots (Jain et al., 1997), shoot proliferation (Buah et al., 2000; García et al., 2002; Karhu, 1997; Marino etal., 1991, 1993; Pua and Chong, 1984), and somatic embryogenesis (Blanc etal., 1999; Daigny et al., 1996; de Paiva Neto and Otoni, 2003; Fuentes et al., 2000; Garin et al., 2000; Loiseau etal., 1995) in many plant species. Sucrose has been used in most studies on shoot proliferation of woody species but studies on shoot proliferation of some woody Rosaceous species, such as apple (Karhu, 1997; Pua and Chong, 1984) and apricot (Marino et al., 1991, 1993), used sorbitol.

In a previous study, we compared the effects of sucrose, sorbitol and glucose on shoot proliferation of pear and found that sorbitol was the best carbon source (Kadota et al., 2001). However, the effect of carbon sources other than sucrose, sorbitol and glucose on shoot proliferation and rooting is unknown. This study was done to better understand how various carbon sources influence shoot proliferation, hyperhydricity and rooting of 'Hosui' pear.

\section{Materials and Methods}

Plantmaterial and culture condition. Shoots of japanese pear (Pyrus pyrifolia N.) 'Hosui'

\footnotetext{
Received for publication 9 June 2003. Accepted for publication 10 Feb. 2004.

${ }^{1}$ Current address:Toyama City HallAgriculture, Forestry \& Fisheries Division7-38 Sin-Sakura, Toyama 930-8510, Japan; e-mail kadota@cd.mbn.or.jp.
}

were subcultured monthly for 20 months in 50 $\times 150$-mm culture vessels containing $30 \mathrm{~mL}$ of shoot proliferation medium [(SPM) woody plant medium (Lloyd and McCown, 1981) with 0.5 $\mu \mathrm{M}$ indole-3-butyric acid (IBA), $11.0 \mu \mathrm{M}$ 6-benzyladenine, $0.8 \%$ (w/v) powder agar (Wako Co. Ltd, Japan)], and $90 \mathrm{~mm}$ sucrose. The medium was adjusted to $\mathrm{pH} 5.7$ before autoclaving at $121^{\circ} \mathrm{C}$ for $10 \mathrm{~min}$. Shoots were illuminated by cool-white fluorescent light $\left(50 \mu \mathrm{mol} \cdot \mathrm{m}^{-2} \cdot \mathrm{s}^{-1}\right.$ per 16-h photoperiod) at $25 \pm 1^{\circ} \mathrm{C}$ (Kadota et al., 2001; Kadota and Niimi, 2003).

Shoot proliferation experiment. Shoot tips (4 to $5 \mathrm{~mm}$ long, 9 to $11 \mathrm{mg}$ ) were cut from the normal explants and were transferred to $25 \times 100-\mathrm{mm}$ culture tubes containing 20 $\mathrm{mL}$ SPM with 30,60 , or $120 \mathrm{~mm}$ of sorbitol, sucrose, fructose, glucose, mannitol, maltose, or lactose. Shoot tips were placed in vertically in the medium with one shoot tip in each tube. Fifteen shoot tips were used in each treatment. The experiment was done four times (60 replications/treatment). After 8 weeks, the survival rate, number of shoots formed for each explant, the percentage of fresh mass increase and the percentage of hyperhydric original explants were recorded. Hyperhydric explants were not included when considering the mean number of shoots and fresh mass increase. Culture vessels were arranged randomly with replicate tubes for each treatment. All response variables were subjected to a two-way ANOVA with carbon source and their concentration.

Rooting experiment. Shoots (10 mm long) were transferred to $25 \times 100$-mm tubes containing $20 \mathrm{~mL}$ of half-strength Murashige and Skoog medium (1962) with $10 \mu$ M IBA, 1.35 mм phloroglucinol (1,3,5-trihydroxybenzene), $0.8 \%(\mathrm{w} / \mathrm{v})$ powder agar (Wako Co., Ltd. Jpn), and $60 \mathrm{~mm}$ each of either sorbitol, sucrose, fructose, glucose, mannitol, maltose, or lactose. Shoots were incubated in the dark for five days before transfer to a similar medium without IBA at a $16 \mathrm{~h}$ photoperiod $\left(50 \mu \mathrm{mol} \cdot \mathrm{m}^{-2} \cdot \mathrm{s}^{-1}\right)$ at 25 $\pm 1{ }^{\circ} \mathrm{C}$ (Kadota et al., 2002). Fifteen shoot tips were used in treatment. The experiment was done four times (60 replications/treatment). Rooting frequency, survival rate, root number and average root length were recorded after $60 \mathrm{~d}$. Data were analyzed by using the least significant difference test at $P \leq 0.05$.

\section{Results and Discussion}

Shoot proliferation experiment. The influence of carbon source and concentration was significant by analysis of variance (Table 1). Shoot multiplication was poor except for explants in $60 \mathrm{~mm}$ sorbitol (3.5) and no concentration of mannitol produced new shoots (Fig. 1). The fresh weight increase was more than eight times different between the worst and best treatments (Fig. 2). The fresh weight increase was higher at $30 \mathrm{~mm}$ sorbitol $(1234.2 \%)$ than at $60 \mathrm{~mm}$ sucrose $(1065.0 \%)$ and $60 \mathrm{~mm}$ sorbitol $(981.7 \%)$, and was lowest at $120 \mathrm{~mm}$ fructose and at all concentrations of mannitol (151.7\% to $186.3 \%)$. The difference in carbon source and concentration effect on shoot number and fresh mass increase was significant (Table 1); lactose, maltose, and mannitol were generally inferior. At $120 \mathrm{~mm}$ the shoot fresh weight increase was lower compared with the other concentrations. Shoot survival with all carbohydrates was $>88 \%$, except for all concentrations of mannitol and $30 \mathrm{~mm}$ lactose and maltose treatments (Fig. $3)$. Explants treated with glucose and sorbitol tended to survive well and then explants treated with sucrose and fructose. Explants treated with mannitol did not survive.

Our previous study showed that sorbitol as the most suitable carbon source, but this result

Table 1. Analysis of variance of shoot proliferation for data taken at 8 weeks after culture initiation from seven carbon sources and three concentrations added in culture medium.

\begin{tabular}{lcc}
\hline Source & $\begin{array}{c}\text { Shoot } \\
\text { no. }\end{array}$ & $\begin{array}{c}\text { Fresh mass } \\
\text { increase }(\%)\end{array}$ \\
\hline Carbon source $(\mathrm{CS})$ & $*$ & $* *$ \\
Concentration $(\mathrm{C})$ & $* *$ & $* *$ \\
$\mathrm{C} \times \mathrm{CS}$ & $* *$ & $* *$ \\
\hline NS,,$* *$ Nonsignificant or significant at $P \leq 0.05$ or \\
0.01 , respectively.
\end{tabular}

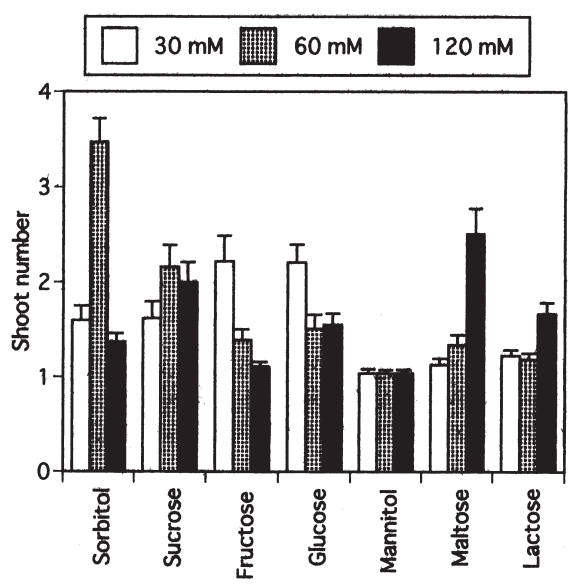

Fig. 1. Influence of carbon source and their concentration on shoot number of Pyrus pyrifolia N. 'Hosui' 


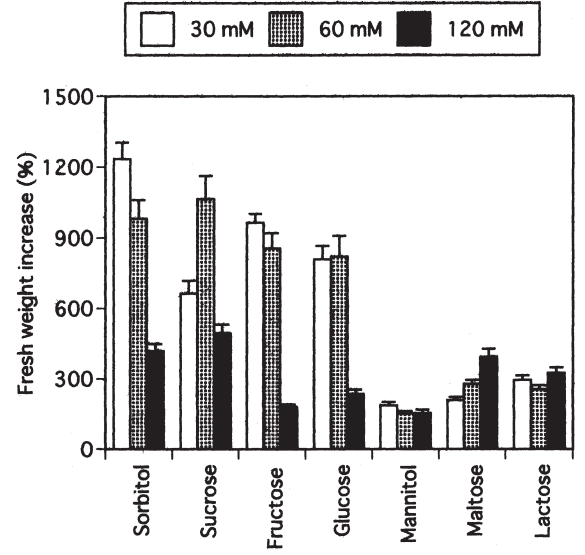

Fig. 2. Influence of carbon source and their concentration on fresh weight increase of Pyrus pyrifolia N. 'Hosui'.

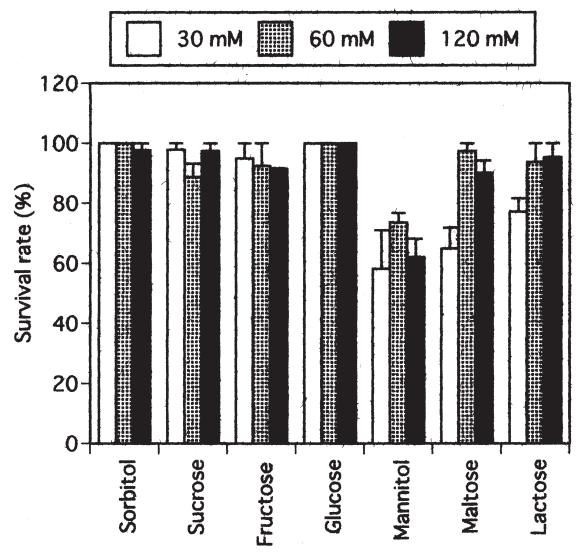

Fig. 3. Influence of carbon source and their concentration on survival rate of Pyrus pyrifolia N. 'Hosui'.

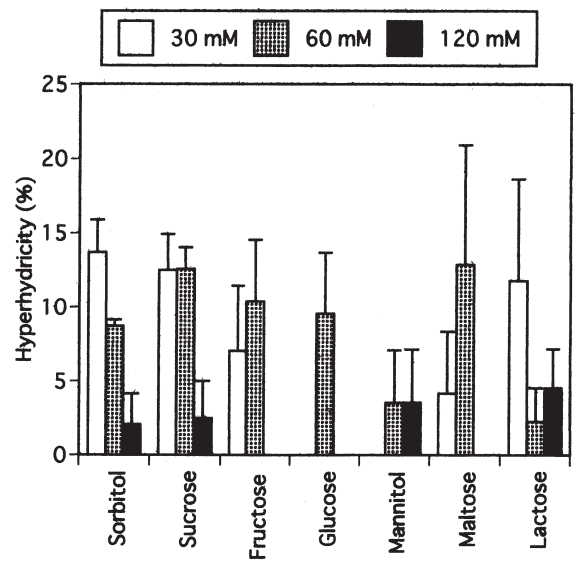

Fig. 4. Influence of carbon source and their concentration on hyperhydricity of Pyrus pyrifolia N. 'Hosui'.

was after only 5 weeks cultivation (Kadota et al., 2001). In this study, we investigated its effect by extending the cultivation time to 8 weeks. As $60 \mathrm{~mm}$ sorbitol induced the highest shoot number and fresh weight increase compared with all other treatments, we concluded that $60 \mathrm{~mm}$ sorbitol was the most effective carbon source at this concentration

Table 2. Effect of carbon sources on rooting of japanese pear 'Hosui'.

\begin{tabular}{lcccc}
\hline $\begin{array}{l}\text { Carbon } \\
\text { source }\end{array}$ & $\begin{array}{c}\text { Survival } \\
\text { rate }(\%)\end{array}$ & $\begin{array}{c}\text { Rooting } \\
\text { frequency }(\%)\end{array}$ & $\begin{array}{c}\text { Root } \\
\text { no. }\end{array}$ & $\begin{array}{c}\text { Root } \\
\text { length }(\mathrm{mm})\end{array}$ \\
\hline Fructose & $96 \mathrm{a}^{\mathrm{z}}$ & $0 \mathrm{c}$ & --- & --- \\
Glucose & $98 \mathrm{a}$ & $10 \mathrm{~b}$ & $1.3 \pm 0.2 \mathrm{~b}$ & $10.0 \pm 2.1$ \\
Lactose & $92 \mathrm{a}$ & $0 \mathrm{c}$ & --- & --- \\
Maltose & $70 \mathrm{~b}$ & $0 \mathrm{c}$ & --- & -- \\
Mannitol & $66 \mathrm{~b}$ & $0 \mathrm{c}$ & $2.0 \pm 0.4$ & --- \\
Sorbitol & $98 \mathrm{a}$ & $12 \mathrm{~b}$ & $2.8 \pm 0.8$ & $36.3 \pm 6.4$ \\
Sucrose & $98 \mathrm{a}$ & $24 \mathrm{a}$ & 6.4 \\
\hline
\end{tabular}

${ }^{\mathrm{z}}$ Mean separation down a column by using the least significant difference test, $P \leq 0.05$.

${ }^{y}$ Mean \pm SE.

for shoot proliferation of japanese pear 'Hosui'. Shoot growth of apple and apricot, two other woody Rosaceous species, accelerated when sorbitol was used as a carbon source in proliferation media (Marino et al. 1993; Pua and Chong 1985). Sorbitol is a main product of photosynthesis and is the transported form of carbohydrate (Bieleski, 1982). Sorbitol is the most effective carbon source for apricot. Also, specific enzymes for sorbitol oxidation are in apricot microshoots and may be responsible for improved shoot production and development when sorbitol is added to a proliferation medium compared with sucrose (Marino et al., 1993). We presume that the same reasons explain our results with 'Hosui' pear. Survival rates and shoot proliferation were low in shoots exposed to mannitol, lactose, and maltose, possibly because the activity of enzymes participating in the metabolism of these carbon sources in pear cells was low.

The highest percentage of hyperhydric explants was at $30 \mathrm{~mm}$ sorbitol $(13.7 \%)$, and was less at $120 \mathrm{~mm}$ fructose and maltose, 30 and $120 \mathrm{~mm}$ glucose, and $30 \mathrm{~mm}$ mannitol $(0 \%)$ (Fig. 4). Hyperhydricity was most prevalent among explants incubated $60 \mathrm{~mm}(8.6 \%)$ and $30 \mathrm{~mm}(7.0 \%)$ with fewer hyperhydric explants at $120 \mathrm{~mm}(1.8 \%)$. A higher carbon source concentration produced the lowest water potential. However, explants cultured in medium with lower carbon concentration under a suboptical light condition grew rapidly because they may absorb inorganic and organic nutrients excessively, so that the explants hyperhydrate. Therefore, to prevent hyperhydricity avoiding retardants in the medium might be necessary.

Rooting experiment. The survival rate of shoots was highest with glucose, sorbitol and sucrose, fructose and lactose $(92.0 \%$ to $98.0 \%)$ and was least with maltose $(70.0 \%)$ and mannitol $(66.0 \%)$ (Table 2). Rooting only occurred when media contained sucrose $(24.0 \%)$, sorbitol $(12.0 \%)$, or glucose $(10.0 \%)$; medium containing sucrose induced the highest root number and root length. The other carbon sources had no effect on rooting. This result indicates that the influence of a carbon source type is marked. The effects of sorbitol and sucrose on rooting have been studied for apple (Pua and Chong, 1985) and apricot (Marino et al., 1991, 1993). Sucrose is generally more effective than sorbitol, and this study showed the same tendency for pear 'Hosui'. Interestingly, shoot proliferation was highest with sorbitol, while rooting was highest with sucrose. Starch often accumulates in the target cells just before regeneration and this starch may be a carbohydrate reserve during meristem formation. Starch is produced from sucrose supplied in the culture medium (Jasik and De Klerk, 1997; Thorpe et al., 1986). The lack of rooting by shoots in media containing mannitol, lactose or maltose may be attributed to the absence or inactivation of enzymes metabolizing these carbon sources.

\section{Conclusion}

The results of this study show that $60 \mathrm{~mm}$ sorbitol is most effective for shoot proliferation, and sucrose is the best carbon source for rooting. They improved plant regeneration that should facilitate micropropagation and breeding of pear cultivars.

\section{Literature Cited}

Bieleski, R.L. 1982. Sugar alcohols, p. 158-290. In: F.A. Loewus and W. Tanner (eds.). Encyclopedia of plant physiology. new ser. Springer Verlag, Berlin.

Blanc, G., N. Michaux-Ferrière, C. Teisson, L. Lardet, and M.P. Carron. 1999. Effects of carbohydrate addition on the induction of somatic embryogenesis in Hevea brasiliensis. Plant Cell Tiss. Org. Cult. 59:103-112.

Buah, J.N., Y. Kawamitsu, S. Yonemori, M. Hayashi, and S. Murayama. 2000. Effects of various carbon sources and their combinations on in vitro growth and photosynthesis of banana plantlets. Plant Prod. Sci. 3:392-397.

Daigny, G., H. Paul, R.S. Sangwan, and B.S. Sangwan-Norreel. 1996. Factors influencing secondary somatic embryogenesis in Malus $\times$ domestica Borkh. (cv 'Gloster 69'). Plant Cell Rpt. 16:153-157.

De Paiva, V.B. and W.C. Otoni. 2003. Carbon sources and their osmotic potential in plant tissue culture: Does it matter?. Sci. Hort. 97:193-202.

Fuentes, S.R.L., M.B.P. Calheiros, J. Manetti-Filho and L.G.E. Vieira. 2000. The effects of silver nitrate and different carbohydrate sources on somatic embryogenesis in Coffea canephora. Plant Cell Tiss. Org. Cult. 60:5-13.

García J.L., J. Troncoso, R. Sarmiento, and A. Troncoso. 2002. Influence of carbon source and their concentration on the in vitro development of olive zygotic embryos and explants raised from them. Plant Cell Tiss. Org. Cult. 69:95-100.

Garin, É., M. Bernier-Cardou, N. Isabel, K. Klimaszewska, and A. Plourde. 2000. Effect of sugars, amino acids, and culture technique on maturation of somatic embryos of Pinus strobes on medium with two gellan gum concentrations. Plant Cell Tiss. Org. Cult. 62:27-37.

Jain, R.K., M.R. Davey, E.C. Cocking, and R. Wu. 1997. Carbohydrate and osmotic requirements for high-frequency plant regeneration from protoplast-derived colonies of indica and japonica 
rice varieties. J. Expt. Bot. 48:751-758.

Jasik, J. and G.J. De Klerk. 1997. Anatomical and ultrastructural examination of adventitious root formation in stem slices of apple. Biol. Plant. 39:79-90.

Kadota, M., T. Hirano, and K. Imizu 2001. Doublephase culture using sorbitol increases in vitro shoot proliferation and reduces hyperhydricity in japanese pear. Sci. Hort. 89:207-215.

Kadota, M., T. Hirano, K. Imizu, and Y. Niimi. 2002. Pyroligneous acid improves in vitro rooting of japanese pear cultivars. HortScience 37:194-195.

Kadota, M. and Y. Niimi. 2002. Effects of cytokinin types and their concentrations on shoot proliferation and hyperhydricity in in vitro pear cultivar shoots. Plant Cell Tiss. Org. Cult.

Karhu, S.T. 1997. Sugar use in relation to shoot induction by sorbitol and cytokinin in apple. J. Amer. Soc. Hort. Sci. 122:476-480.
Kozai, T. 1991. Micropropagation under photoautotrophic conditions, p. 447-469. In:P.C. Debergh and R.H.Zimmerman (eds.). Micropropagation: Technology and application. Kluwer Academic Publ., Dordrecht, The Netherlands.

Lloyd, G. and B. McCown. 1981. Commerciallyfeasible micropropagation of mountain laurel, Kalmia latifolia, by use of shoot-tip culture. Proc. Intl. Plant Prop. Soc. 30:421-427.

Loiseau, J., C. Marche, and Y.L. Deunff. 1995. Effects of auxins, cytokinins, carbohydrates and amino acids on somatic embryogenesis induction from shoot apices of pea. Plant Cell Tiss. Org. Cult. 41:267-275.

Marino, G., G. Bertazza, E. Magnanini, and A.D. Altan. 1993. Comparative effects of sorbitol and sucrose as main carbon energy sources in micropropagation of apricot. Plant Cell Tiss. Org. Cult. 34:235-244.
Marino, G., E. Magnanini, S. Battistini, and B. Righetti. 1991. Effect of hormones and main carbon enegy sources on in vitro propagation of apricot (Prunus armeniaca L.) cvs. 'San Castrese' and 'Portici'. Acta Hort. 293:355-362.

Murashige, T. and F. Skoog. 1962. A revised medium for rapid growth and bioassays with tobacco tissue culture. Physiol. Plant. 15:478-497.

Pua, E.C. and C. Chong. 1984. Requirement for sorbitol (D-glucitol) as carbon source for in vitro propagation of Malus robusta No. 5. Can. J. Bot. 62:1545-1549.

Pua, E.C. and C. Chong. 1985. Regulation of in vitro shoot and root regeneration in 'Macspur' apple by sorbitol (D-glucitol) and related carbon sources. J. Amer. Soc. Hort. Sci. 110:705-709.

Thorpe T.A. and T. Murashige. 1968. Starch accumulation in shoot-forming tobacco callus cultures. Science 160:421-422. 